DOI: $10.14451 / 2.136 .11$

\title{
ОСОБЕННОСТИ ПРАВОВОГО РЕГУЛИРОВАНИЯ МЕСТНОГО САМОУПРАВЛЕНИЯ НА ТЕРРИТОРИИ РЕСПУБЛИКИ КРЫМ
}

\author{
(c) 2019 Гаевская Анна Владимировна \\ аспирант \\ Кафедра правового обеспечения государственной гражданской службы \\ Институт государственной службы и управления \\ Российская академия народного хозяйства и государственной службы \\ при Президенте Российской Федерации, Россия, Москва \\ E-mail: anna.v.gaevskaya@gmail.com
}

В статье рассматриваются особенности правового регулирования местного самоуправления в Республике Крым. Представлены наиболее значимые проблемы с которыми столкнулся Крым в период интеграции в состав Российской Федерации и формирования собственной модели местных органов власти. Автором статьи предложены ключевые направления правового регулирования и развития местного самоуправления в новом субъекте России.

Ключевые слова: местное самоуправление, муниципальная служба, переходный период, Министерство по делам Крыма, Правительственная Комиссия.

Республика Крым и город федерального значения Севастополь как новые субъекты Российской Федерации на момент интеграции нуждались в специальной системе организации публичной власти. Специфика организации местного самоуправления предопределялась комплексом обстоятельств, приведенных в настоящем исследовании.

Очевидно, что одномоментное изменение законодательства во всех сферах, а также приведение в исполнение вновь принятых положений было невозможно. Поэтому в статье 6 Федерального конституционного закона от 21.03.2014 № 6-ФКЗ «О принятии в Российскую Федерацию Республики Крым и образовании в составе Российской Федерации новых субъектов - Республики Крым и города федерального значения Севастополя» установлен конкретный срок переходного периода действующий до 1 января 2015 года с целью осуществления интеграции в правовую, финансовую, экономическую системы России, а также в систему органов власти Российской Федерации [13].

Для создания правовых условий адаптации всех секторов экономики Крыма и социальной сферы к правовой системе России было принято 8 федеральных конституционных законов, 32 федеральных закона и свыше 600 подзаконных актов.

Только Государственным Советом Республики Крым было принято 19 законов регулирую- щих вопросы местного самоуправления на территории Республики Крым.

Учитывая тот факт, что местная власть непосредственно связана с населением, наиболее важным нормативным документом принятым в Республике Крым по вопросу организации местного самоуправления является Закон Республики Крым от 21.08.2014 № 54-ЗРК «Об основах местного самоуправления в Республике Крым» [2].

Необходимо осознавать, что формирование законодательства в кратчайшие сроки приходилось уже на существующую и действующую основу законодательства Российской Федерации, что в свою очередь значительно облегчало процесс, а также позволяло учесть собственные исторические особенности и не допустить отрицательный опыт иных субъектов Российской Федерации с практической стороны.

С целью эффективного и полноценного интегрирования Республики Крым и города федерального значения Севастополя в состав Российской Федерации указом Президента Российской Федерации 31 марта 2014 г. было создано Министерство Российской Федерации по делам Крыма.

Основными задачами министерства являлись разработка проектов государственных программ по развитию Крыма и контроль за их реализацией, также ведомство координировало деятельность органов федеральной исполни- 
тельной власти на территории полуострова.

Одной из главных задач Министерства по делам Крыма в 2014 г. была разработка федеральной целевой программы «Социально - экономическое развитие Республики Крым и г. Севастополя до 2020 года». Цель была достигнута 11 августа 2014 г. путем утверждения программы Правительством Российской Федерации. Реализация, указанной программы направлена на решение различного спектра экономических проблем, а также устранение инфраструктурных ограничений, препятствующих социально экономическому развитию полуострова [4].

В скором времени указом Президента Российской Федерации от 15.07.2015 № 368 Министерство Российской Федерации по делам Крыма было ликвидировано «в связи с завершением переходного периода, предусмотренного Федеральным конституционным законом от 21 марта 2014 г. № 6-ФКЗ», а также в целях оптимизации структуры федеральных органов исполнительной власти. Упразднение Минкрыма повлекло внесение очередных изменений в положение о Минэкономразвитии России в связи с передачей ему функций ранее действующего министерства [11] [1, С.15-16].

Официально объявленный переходный период был завершен, в свою очередь статья 12.1 Федерального конституционного закона от 21 марта 2014 г. № 6-ФКЗ предусматривает особый порядок регулирования отдельных отношений (сфер законодательства) таких как лесных, имущественных, земельных, градостроительных и других на территориях Республики Крым и города федерального значения Севастополя, которые все еще требуют сторонней координации деятельности органов власти, а также организаций.

В связи с дальнейшей необходимостью обеспечения согласованных действий федеральных органов исполнительной власти, органов исполнительной власти субъектов Российской Федерации, органов местного самоуправления, иных органов и организаций при решении вопросов, направленных на социально-экономическое развитие региона распоряжением Правительства Российской Федерации от 24.07.2015 № 1439-р образована Правительственная комиссия по вопросам социально-экономического развития Республики Крым и города Севастополя [8].

Комиссия является координационным орга- ном, а также выполняет функции по осуществлению контроля за реализацией указанных решений. Согласно положению о Правительственной комиссии, утвержденного Постановлением Правительства Российской Федерации от 20.08.2015 № 869 заседания Правительственной комиссии проводятся по решению председателя Правительственной комиссии, но не реже одного раза в квартал. В полномочия Правительственной комиссии также входит создание временных и постоянных рабочий групп, например существует рабочая группа по социальным вопросам Республики Крым и г. Севастополя, заседания которой состоялись. В свою очередь невзирая на положение заседания Правительственной комиссии с момента создания проведены не были несмотря на то, что проблемные вопросы в различных секторах экономики на территории полуострова присутствуют [5].

Первостепенной задачей регулирования местного самоуправления Республики Крым было формирование подготовленного профессионального состава должностных лиц и муниципальных служащих в рамках нового законодательства без потери уровня и качества оказываемых органами местного самоуправления услуг населению.

На реализацию указанной задачи были направлены следующие проекты:

1) Федеральная целевая программа «Социально-экономическое развитие Республики Крым и г. Севастополя до 2020 года, утвержденная Постановлением Правительства Российской Федерации от 11.08.2014 № 790 включает в том числе мероприятия направленные на подготовку и переподготовку кадрового состава органов власти Республики Крым и города Севастополя [4].

2) Государственная программа Республики Крым «Развитие муниципальной службы Республики Крым на 2017-2019 годы», утвержденная постановлением Совета министров Республики Крым от 20.12.2016 № 611 с целью повышение эффективности и качества муниципального управления при помощи системы профессиональной подготовки, переподготовки, повышения квалификации, а также иных форм обучения муниципальных служащих, ориентированных на решение практических задач органов местного самоуправления [6].

3) Проект «Крымский вектор» реализован в Крыму Красноярским Институтом муниципаль- 
ного развития в целях переобучения и повышения квалификации муниципальных служащих, а также преодоления сформировавшейся психологии чиновников, которые привыкли «каждый свой шаг согласовывать со столицей».

4) Проект «День методической помощи в муниципальном образовании» разработан Крымским региональным отделением Общероссийской общественной организации «Ассоциация юристов России» и нацелен на предоставление практической юридической помощи работникам местных органов власти при осуществлении своих полномочий, повышение профессионального уровня муниципальных служащих, повышение уровня взаимодействия органов государственной власти и местного самоуправления, улучшение качества предоставления муниципальных услуг населению. Такой проект не имеет аналогов, хотя необходимость повышения уровня знаний муниципальных служащих прослеживается не только на полуострове.

5) Утверждение муниципальных программ развития муниципальной службы на местном уровне позволяет сформировать эффективный состав кадров, в том числе кадровый резерв муниципальных служащих, совершенствования их знаний и умений (пример: постановление Администрации города Алушты Республики Крым от 07 ноября 2017 года № 2256 «Об утверждении муниципальной программы «Развитие муниципальной службы в Администрации города Алушты Республики Крым на 2018-2020 годы» [7] [2, С. 13-14].

До 2014 года в регионе при Совете министров Автономной Республики Крым действовал Крымский центр переподготовки и повышения квалификации работников органов государственной власти, органов местного самоуправления, и подотчетных им предприятий и учреждений. Центр предоставлял следующие образовательные услуги: обучение согласно специально подготовленным профессиональным программам, проведение семинаров по востребованным тематикам, а также проведение консультаций научным составом. В свою очередь распоряжением Совета Министров Республики Крым от 04.06.2014 № 469-р был ликвидирован [9].

До сих пор аналогичный центр на территории республики создан не был, однако его уч- реждение в период интеграции способствовала бы решению многих задач в части переподготовки специалистов, а также подготовки новых, молодых специалистов к службе в органах местного самоуправления.

Развития территории Республики Крым и города Севастополя в период интеграции также имело свои особенности.

Так в связи с образованием в составе Российской Федерации новых субъектов указом Президента Российской федерации от 21 марта 2014 № 168, в тот же день что и принятие федерального конституционного закона, был образован Крымский федеральный округ [10].

В России федеральный округ представляет собой территорию, включающую в себя несколько субъектов РФ, в рамках которой действует полномочный представитель Президента РФ. На территории России создано 8 федеральных округов, Крымский федеральный округ являлся девятым. Полномочный представитель осуществляет организацию взаимодействия федеральных органов исполнительной власти с органами государственной власти субъектов РФ, органами местного самоуправления, политическими партиями, иными общественными и религиозными объединениями; принимает участие в разработке совместно с межрегиональными ассоциациями экономического взаимодействия субъектов РФ программ социально-экономического развития территорий в пределах федерального округа. В связи с особенностью нахождения в одном федеральном округе нескольких субъектов Российской Федерации на этапе интеграции Крыма в Россию была очевидна необходимость создания отдельного федерального округа.

Указом Президента Российской Федерации от 28.07.2016 № 375 в целях повышения эффективности деятельности федеральных органов государственной власти Южный федеральный округ и Крымский федеральный округ были преобразованы в Южный федеральный округ. Упразднение округа - это следствие того, что полуостров окончательно интегрировался в Россию [12].

Предложенные стимулы в сфере развития местного самоуправления позволят сформировать благоприятную среду для повышения качества регулирования местного самоуправления на территории Республике Крым. 


\section{Библиографический список}

1. Занко T.A. Анализ периодичности внесения изменений в положения о федеральных органах исполнительной власти // Административное и муниципальное право. 2017. № 8. - С. 14-18.

2. Закон Республики Крым от 21.08.2014 № 54-3РК «Об основах местного самоуправления в Республике Крым» // Крымские известия.- 2014.- o 172.-(5583).

3. Киреева Е.Ю. Программы развития муниципальной службы: от норм к действию // Административное и муниципальное право. 2018. № 9 (129). С. 10-17.

4. Постановление Правительства Российской Федерации от 11 августа 2014 г. № 790 «Об утверждении федеральной целевой программы «Социально-экономическое развитие Республики Крым и г. Севастополя до 2022 года» //СЗ РФ от 18 августа 2014 г. № 33 ст. 4595. URL: http://www.pravo.gov.ru/ (дата обращения: 18.02.2020).

5. Постановление Правительства Российской Федерации от 20 августа 2015 г. № 869 «Об утверждении Положения о Правительственной комиссии по вопросам социально-экономического развития Республики Крым и г. Севастополя»//СЗ РФ от 31 августа 2015 г. № 35 ст. 4988. URL: http://www.pravo.gov.ru/ (дата обращения: 18.02.2020).

6. Постановление Совета министров Республики Крым от 20.12.2016 № 611 Государственная программа Республики Крым «Развитие муниципальной службы Республики Крым на 2017-2019 годы». URL: http://www. pravo.gov.ru/ (дата обращения: 18.02.2020).

7. Постановление Администрации города Алушты Республики Крым от 07 ноября 2017 года № 2256 «Об утверждении муниципальной программы «Развитие муниципальной службы в Администрации города Алушты Республики Крым на 2018-2020 годы». URL: http://www.pravo.gov.ru/ (дата обращения: 18.02.2020).

8. Распоряжение Правительства Российской Федерации от 24 июля 2015 г. № 1439-p URL: http://www.pravo. gov.ru/ (дата обращения: 18.02.2020).

9. Распоряжение Совета Министров Республики Крым от 04.06.2014 № 469-p. URL: http://www.pravo.gov.ru/ (дата обращения: 18.02.2020).

10. Указ Президента Российской федерации от 21 марта 2014 № 168 //СЗ РФ от 24 марта 2014 г. № 12 ст. 1265. URL: http://www.pravo.gov.ru/ (дата обращения: 18.02.2020).

11. Указ Президента Российской Федерации от 15.07.2015 № 368 //С3 РФ от 20 июля 2015 г. № 29 ст. 4479. URL: http://www.pravo.gov.ru/ (дата обращения: 18.02.2020).

12. Указ Президента Российской Федерации от 28.07.2016 № 375 //С3 РФ от 01 августа 2016 г. № 31 ст. 4984. URL: http://www.pravo.gov.ru/ (дата обращения: 18.02.2020).

13. Федеральный конституционный закон от 21 марта 2014 г. № 6-ФКЗ «О принятии в Российскую Федерацию Республики Крым и образовании в составе Российской Федерации новых субъектов - Республики Крым и города федерального значения Севастополя» //С3 РФ от 24 марта 2014 г. № 12 ст. 1201. URL: http://www. pravo.gov.ru/ (дата обращения: 18.02.2020). 